\title{
The Competence of Islamic Religious Education Teachers Perspective K.H. Hasyim Asy'ari
}

\author{
Tasurun Amma', M. Saiful Bahri², and Ahmad Munawir ${ }^{3}$
}

1STEBIS Darussalam OKI

2STEBIS Darussalam OKI

3STEBIS Darussalam OKI

\begin{abstract}
A professional teacher is meets several classifications, including the individual is a teacher with recognized, has teacher expertise or what is often called expertise in certain scientific fields related to his profession as a teacher, fulfills the aspects of coaching and development. who go through formal education or non-formal coaching. This research focuses on the competence of Islamic Religious Education teachers in the perspective of Kiai H. Hasyim Asy'ari, especially referring to his book Adabu Al-Alimi Wal Muta'alim. This type of research uses a type of library research. The primary data is from Adabu Al-Alimi Wal Muta'alim The results of this study are three teacher positions according to KH. Hasyim Asy'ari, namely teachers as individual teachers regarding personal religious, teachers when teaching, and teachers to students. The pedagogic competence indicator according to KH. Hasyim Asy'ari includes the attitude of purifying himself from all things that are not blessed by Allah Almighty, visionary, and having knowledge. Personality competence covers a calm person, tawakal, tawadhu ', and an independent person ,. Professional competence according to KH. Hasyim Asy'ari is a teacher's ability in knowledge and good at managing class. Social competence, according to KH. Hasyim Asy'ari is good at choosing jobs, good at choosing communities where to gather, avoiding places that socially can reduce the degree of teachers, and able to interact well.
\end{abstract}

\section{ARTICLE \\ INFORMATION}

Keywords:

Teacher's

Competence,

Islamic of

Education, $\mathrm{KH}$.

Hasyim Asy'ari 


\section{Introduction}

Teachers are responsible for the implementation of the national education system and the achievement of national education goals, this is related to the responsibility of a professional teacher, referring to the Law No. 20 of 2003 concerning the National Education System the goal is to develop the potential of students to become human beings who believe and fear God Almighty, have noble character, are healthy, knowledgeable, capable, creative, independent, and become democratic and responsible citizens. The implementation of teacher duties in achieving these lofty goals requires strategic efforts in maximizing the functions and roles of individual teachers, including exercising their rights and obligations as professional teachers which also include improvement and development of professional teacher pedagogy, legal umbrella and professional policies, and physical and spiritual protection rights as well as comfort at work.

Indonesian people are then expected to have qualities that are able to compete in the international arena. This will be realized through the implementation of quality education, so that the role of a teacher must be able to become a motivator and modifier in carrying out the realization of quality education. The functions, roles and positions of teachers are very strategic in Article 39 Paragraph (2) of the Law. Number 20 of 2003 concerning the National Education System states that an educator is a professional staff. The position of teachers and lecturers as professionals has a vision for the realization of the implementation of learning in accordance with the principles of professionalism to fulfill the equal rights of every citizen in obtaining quality education.

The implementation of quality education must be supported by the creation of professional educators. Republic of Indonesia Law No. 14 of 2005 concerning Teachers and Lecturers mentioning that the profession of a teacher has a very heavy responsibility, apart from educating and teaching, someone who is said to be a teacher must also be a supervisor, director, trainer, and evaluator for students. A teacher / educator can be said to be a professional if he meets several classifications, including having recognition that the individual is a teacher with recognized evidence, has teacher expertise or what is often called expertise in certain scientific fields related to his profession as a teacher, fulfills the aspects of coaching and development. who go through formal education or non-formal coaching, then the teacher is worthy of being said to be a professional teacher, namely teachers with the ability to plan, realize, and realize education and learning.

Focus in terms of teacher professionalism, Indonesia in Law Number 14 of 2005 concerning Teachers and Lecturers: it is stated that a teacher is required to fulfill The competence of a teacher includes pedagogical, personal, 
social, and professional competencies through education conducted by the state or private sector regarding the profession. Islamic education has a high respect for the figure of a teacher. As a teacher or educator, he clearly has virtues that should be respected, appreciated, and obeyed.

Islamic education places the teacher as a very important individual, the meaning and role of a teacher can be felt in various attitudes in learning. ${ }^{1}$ Teachers are spiritual healers and directors of students seriously and continuously become the main role in motivating students. The teacher is a person who presents the needs of the soul in the form of knowledge, a pioneer in carrying out morals, and change bad behavior to be good. The teacher's duty to the next student is to provide direction to students both for personal life including education, religion, and science as well as in social life such as socializing and how to interact with society. That is why Islamic education positions teachers in a higher degree. ${ }^{2}$

In Islamic education itself, teachers have been discussed in various studies of the yellow book, all their attitudes and competencies as teachers are discussed and studied in many Islamic boarding school study forums, being a teacher in

1 Kurniati, K., Nurdin, N., \& Nurasmawati, N. (2020). Improving Students' Cognitive and Affective Domains Students through Fostering Teacher Development International Journal of Contemporary Islamic Education, 2(2), 56-70.

2 Nur Uhbiyati, Ilmu Pendidikan Islam, (Bandung: Pustaka Setia, 1998), 65. the scope of Islamic education has many qualifications that must be mastered, especially having faith. and devotion to Allah, civilized and have a qualified science. The teacher's task for the next student is to provide direction to students both for personal life including education, religion, and science as well as in social life such as socializing and how to interact with society. That is why Islamic education positions teachers in a higher degree. ${ }^{3}$

In Islamic education itself, teachers have been discussed in various studies of the yellow book, all their attitudes and competencies as teachers are discussed and studied in many Islamic boarding school study forums, being a teacher in the scope of Islamic education has many qualifications that must be mastered, especially having faith. and devotion to Allah, civilized and have a qualified science.

\section{Literature Review}

Teachers are a profession that is in great demand by the community, especially supported by the acceptance of Civil Servants. The impact is that there are a lot of tertiary outputs, especially teachers who then randomly become a teacher who sometimes is not yet proficient in their profession as a teacher or has not fulfilled the competence as a professional teacher both in science, teaching ability and the field of study being taught. Teachers

91.
3 Nur Uhbiyati, Ilmu Pendidikan Islam, 
themselves in the perspective of Islam have competencies that must be met in order to be said to be professional. These competencies must be mastered and implemented as a form of professionalism and glorify knowledge, some of the competencies of teachers in the study of the yellow book include personality which includes their faith, attitudes, social and cognitive.

Furthermore, the research focused on exploring the competence of Islamic Religious Education teachers in the perspective of Kiai H. Hasyim Asy'ari, especially referring to his book Adabu Al-Alimi Wal Muta'alim, which is a famous yellow book studied in Islamic boarding schools, especially in Indonesia.

As a form of service that is needed in human life, of course, teachers must have standard skills. The standard proficiency in question is the criterion by which a person is fit or not worthy of entering the profession, so that in carrying out duties and responsibilities, it can be realized in order to achieve the planned goals. Teacher competence is defined as a certain position with a predetermined size and is required with several conditions that must be met, among these are the mastery of science, having good attitudes and behavior so that they can be said to be appropriate in carrying out functional positions as well as educational qualifications and women in society. .

Profession as a teacher then gives the meaning that not everyone can and is worthy of carrying out the profession, it takes criteria, conditions, and qualifications that must be met. This is also in accordance with the understanding of the teacher as a profession written by Moh. Uzer and quoted by Abdul Majid said that a teacher is a position / job with certain abilities or expertise and special requirements so that it is necessary to master the ins and outs of education and knowledge in teaching and master certain disciplines or other knowledge as ability developers, with formal learning methods or learning. additional in the form of workshops, seminars and others. ${ }^{4}$

Competency is the ability /competence of teachers to apply and modify the atmosphere of teaching and learning activities by selecting and developing the presentation of knowledge transfer and material selection in learning activities so that students can easily understand and can implement it in life. ${ }^{5}$ According to Sadirman, the word competence contains two aspects of ability, namely the ability to foster behavior or activities that allow it to be evaluated and studied, as well as abilities regarding

4 Abdul Majid, Belajar dan Pembelajaran Pendidikan Agama Islam, (Bandung, PT. Remaja Rosdakarya, 2012). 85.

${ }^{5}$ Evita, E., Syahid, A., \& Nurdin, N. (2019). Understanding Students' Learning Outcomes Differences Through the Application of the Market Place Activity Type of Cooperative Learning Model and the Application of Conventional Learning Models International Journal of Contemporary Islamic Education, 1(1), 6785. 
the depth of scientific understanding, habituation of feelings in individuals, and how to apply learning. In term, competence is all the abilities (abilities) of the teacher which includes pedagogical, dedactic and methodical abilities. ${ }^{6}$ The pedagogical science in question is the science of educating a child until he is an adult. A didactic term is knowledge about interactions in learning, learning and teaching, learning plening and evaluating learning outcomes. related methodology can be interpreted as knowledge about the ways or techniques and processes of teaching a field of knowledge to students.

According to Moh. As quoted by Usman, Uzer gives the meaning of teacher competencythe ability and accuracy of teachers in being responsible for carrying out their duties. Teacher competence is the ability of teachers to carry out their duties responsibly and properly. ${ }^{7}$ Law of the Republic of Indonesia No. 14 of 2005 article 1 paragraph 10 , states that teachers and lecturers are about teacher competence, where teacher competence is a set of knowledge, skills, and behaviors that must be possessed, lived in, mastered and actualized by teachers in carrying out their professional duties. It can be concluded that what is meant

6 Winarno Surakhmad, Pengantar Penelitian Ilmiah Dasar Metode Teknik. (Bandung: Tarsito 2001). 9.

7 Moh Uzer Usman, Menjadi Guru Proffessional (Bandung : Remaja Rosdakarya, 2009). 14. by teacher competence is self-quality which includes the ability of a teacher to carry out teacher duties as a profession in order to be able to achieve the expected goals.

The role of teachers in providing education and learning guidance for students also has a further impact, namely changes in behavior in life and the social development of the surrounding community, teachers in society are also expected to have the best role. The role of teachers in society can be manifested in various forms, namely; being an agent of social reformer means being able to broadcast the truth, being social control, supporting community work activities, and maintaining the noble values that exist in the community. In the field of teaching, teachers as organizers carry out tasks in the form of providing learning facilities for students, able to guide the learning process of students. In addition, teachers are also able to be good role models for their social environment, which includes students.

Types of Teacher Competencies Teacher competencies are classified into four competencies, namely; pedagogic, personal, social, and professional competences. $^{8}$

Pedagogic Competence, Pedagogic competence, namely the ability of teachers to know the backgrounds of

\footnotetext{
8 Nanang Hanafiah, Cucu Suhana, Konsep Strategi Pembelajaran, (Bandung: PT. Repika Aditama, 2010), 104.
} 
students. ${ }^{9}$ Starting from planning or planning, learning applications, class control, and providing assessment of learning outcomes. This is also commonly referred to as teacher understanding in preparing learning plans for students, implementing learning, and evaluating and also providing feedback for solutions for students.

Personality competence is the teacher's individual ability regarding behavior or habits in acting and mental stability in everyday life. This personality is the provision for the teacher in providing knowledge so that it is always focused on good things.

Social Competence, Social Competence is the ability to act objectively without discrimination, an attitude of being able to adapt to the surrounding environment, and the ability to establish communication in other professional and professional communities textually and contextually. ${ }^{10}$

Professional competence, the ability in intellectual fields, including the ability to understand learning both from the material and its implementation and the ability to collaborate with colleagues.

Apart from the four competencies above, as a pioneer in developing a standard of living in the school and

\footnotetext{
${ }^{9}$ Abdul Majid, Belajar dan Pembelajaran Pendidikan Agama Islam, 92.

10 Abdul Majid, Belajar dan Pembelajaran Pendidikan Agama Islam, (Bandung, PT. Remaja Rosdakarya, 2012). 93.
}

community environment, the competencies of professional Islamic religious education teachers that must also be fulfilled are:

Spiritual competence, spiritual competence, is actually a good heart condition which then causes action based on good intentions. ${ }^{11}$ This competency is an initial requirement in carrying out duties as a teacher of Islamic religious education. Some of the indicators shown in this competency are; considers teaching to be worship, considers learning to be a gift and a mandate, teaching is a calling and a form of devotion to God, realizes that teaching is a noble profession as a form of self-actualization in order to be the best human being and increase human dignity, also considers that teaching is a service where it is needed by the community.

Leadership competence, according to Kilinc, is the existence of teachers as leaders when in the environment of students (class) and the surrounding community (school, home, and other social environments), as well as the ability to contribute to the student community and have a positive influence in improving educational practice. . Teacher leadership in question is the teacher's real effort in giving a positive influence to people or the environment by utilizing the knowledge and authority that he has

11 Zulfatmi, (2017). Kompetensi Spiritual Pendidik (Suatu Kajian pada Unsur Kalbu). Jurnal MUDARRISUNA: Media Kajian Pendidikan Agama Islam. 7. 149. 
both in the school environment or in the surrounding community. ${ }^{12}$ The meaning is that Islamic religious education teachers must always have a leadership spirit. Being a leader here is not necessarily a formal one but rather gives a more dominant color and becomes a place to ask questions or a probem solver for the environment both in school life and society. It is clearer that as a teacher who has a leadership spirit, he must constantly develop himself to be better, have broad insight, active, confident, and ready to be a good example for his environment.

\section{Methodology}

This type of research uses library research research using a study center in the form of an Arabic book, namely the Adabul Mu'alim Wal-Muta'alim Book. So that the data collected is data in the form of writing (textual). The primary source of data is the Book of Adabul Mu'alim Wal Muta'alim. This book is the main source in finding data on teacher competence in KH's view. Hashim Asy; ari. The resulting data from this book is also called first hand data. The data obtained were then analyzed using contextual descriptive qualitative data analysis.

\section{Results And Discussion}

\footnotetext{
12 Zumrotul Mukaffa, (2018). Deprivasi Relatif Kompetensi Kepemimpinan Guru PAI: Kajian Komparatif Guru Akidah Akhlak Berkualifikasi S1 dan Guru Tugas Pesantren Lulusan MA, Jurnal Epistemé, Vol. 13, No. 1, Juni
}

KH Hasyim Asy'ari expressed his opinion in the book Adabul'alim Wal Muta'alim that teachers can be classified into three positions, namely teachers as individuals, teachers when teaching, and teachers towards students. ${ }^{13}$ In the three classifications, he then explained the indicators of teacher competence that must be had related to learning and their implementation in detail as follows;

Teachers as Individuals, is the competence or ability of teachers regarding religious personal. ${ }^{14}$ This means that a teacher must have an attitude or ability regarding the teacher's personal self, including the teacher's religious attitude, exemplary, wise and has an attitude of affection. This competence is also supported by several taboos and recommendations that must be maintained and applied by teachers regarding themselves. The competencies that must be possessed by teachers as individuals include three categories, namely the attitude of a teacher, taboos and recommendations as a teacher.

Teachers when teaching, the activities of a teacher begin with planning teaching and learning, implementing it, until the learning process ends. $\mathrm{KH}$ Hasyim Asy'ari gave his opinion that for a teacher to always

${ }^{13}$ Muhammad Hasyim Asy'ari, Adab al'Alim wa al-Muta'allim, (Jombang: Turats alIslamy, $1515 \mathrm{H}) .15$.

14 Abdul Majid, Belajar dan Pembelajaran Pendidikan Agama Islam, (Bandung, PT. Remaja Rosdakarya, 2012). 85. 
be available in learning by making the best preparation in teaching.

Teachers towards students, Teaching and learning activities including the interaction of teachers and students.

The teacher's competence of $\mathrm{KH}$ Hasyim Asy'ari perspective

\section{a. Pedagogic competence}

Article 28 paragraph 3 of the National Education Standards that what is meant by pedagogical competence is the ability to manage student learning. The explanation is the extent to which the teacher's ability to manage the learning process in educational units from planning to assessment, furthermore that this pedagogical competence requires teachers to understand the background of their students' abilities as a first step or foundation in determining learning plans so that students can be encouraged to grow develop the potential that he has.

Pedagogic competence includes several aspects, namely;

1) Understand learner

Students' understanding can be done withperform an analysis of aspects the development of students includes personal development, social development, and emotional learners.

Furthermore, aspects of diversity or good social and economic background aspects of students, and aspects of students' interest and motivation to learn.
2) Designing learning

Determining learning objectives, including the results achieved by students, conducting Instructional Analysis, covering objectives covering cognitive, affective and psychomotor abilities, knowing the character of students and determining the appropriate learning context, determining specific learning objectives. Includes objectives that have specifically been included in student learning materials, designing evaluation or assessment instruments, this instrument is intended to be a valid assessment reference and can measure students' abilities, develop instructional strategies, determine and develop teaching materials, create and develop evaluations regarding the analysis of learning programs that have been compiled, and follow-up learning programs, in the form of revisions of formative evaluations carried out

3) Implementing learning

After being planned and designed, the learning program is carried out with these guidelines

4) Planing and actuating learning assessment

Conducting comprehensive evaluations with instruments that can be measured from the implementation of learning.

5) Actualization of student potential 
Includes providing programs to increase the interest of students' talents through activities and guidance.

The pedagogic competence indicator according to $\mathrm{KH}$. Hasyim Asy'ari, namely:

Always purify from hadats and unclean and look the best. In addition to preparing themselves with learning tools, teachers should also prepare themselves physically and $\mathrm{KH}$ Hasyim Asy'ari gave his advice to teachers to always look polite and the best with a good character too. In addition, while his inner readiness by praying, remembering Allah and his heart is always accompanied by the words toyibah.

Teachers are good at positioning themselves in the middle of learning in front of the participants they teach. In addition, teachers always have the same view of their students with the attitude of glorifying people who are enthusiastic in seeking knowledge, by providing answers to the problems asked by students if they really want to be known with a good attitude such as the direction of view aimed at students. and showed enthusiasm for the question.

The teacher habituate in reading the Koran, including when starting lessons. As a form of Islamic scientific application, of course the teacher will always invite positive things, in learning habituation the teacher must also turn on religious activities in their students. In addition to expecting a reward from Allah reading the Koran before studying, of course, it is expected that the blessing of ease in learning and remembering all knowledge is from Allah SWT.

Teachers have good intentions. What is meant here is that teachers provide education to students solely because of Allah SWT, with that purpose other good goals will follow such as eliminating ignorance, worship carrying out His orders, maturing students, and spreading Islam. That way if the teacher has good and sincere goals, in carrying out the task, they will not feel tired of all the obstacles that exist in the implementation of the learning process.

The teacher has a sincere will and intention. Teachers are not an easy profession, every behavior and speech can have an impact on students. So in carrying out the mandate as a teacher, it is necessary to start with a sincere will and intention so that in carrying out its duties the teacher is able to be aware of the risks, obstacles, and challenges. A teacher who has a sincere will and intention certainly does not give up easily and will always strive for the good of scientific transfer to students.

The teacher approaches students. Student identifiers can also be said to know the person and ability of the teacher himself, by getting to know students well, the teacher can take appropriate approaches to students in learning. In addition, teachers can also self-reflect on their ability to educate and transfer knowledge.

\section{b. Personality competence}

Personality Competencies is the individual abilities of teachers related to 
teacher behavior and personalities as role models for students. personality competence covers several aspects, namely; a solid and calm person, an independent person, wise, dignified, noble, and always reflects an attitude of maturity in accordance with the prevailing norms. There are indicators of personal competence in KH. Hasyim Asy'ari, namely:

Calm down, as conveyed by the caliph Umar Bin Khottob that a person has an obligation to learn and understand knowledge, besides that he recommended studying calm in nature and tawadhu attitude. A teacher who has a calm attitude in his manner will have an impact on his authority and the right way of acting.

Wara', which is an attitude in which a person is always careful in his actions or always thinks about his every action in order to avoid mistakes or commit immoral acts against Allah. ${ }^{15}$ This attitude creates an attitude that is always directed, has a reference in action and is ready to be an example for his students.

Tawadhu', a behavior that shows that humans always feel small in front of Allah and are not arrogant. This attitude is reflected in several behaviors such as not showing off or looking for faces, not feeling self-righteous, accepting and respecting each other's servants of Allah, realizing that before Allah all creatures are the same except for their deeds and

15 Kholid Syamhudi, Hakikat Wara' Dalam Https://Muslim.Or.Id/9865-HakikatWara'.Html. Diakses Pada 23 Mei 2020. worship. Nor does he feel puffed up about the profession he is in, so he is also easy to forgive the mistakes of others.

Khusyu', According to Al-Ghazali, there are six reflections of khusyu' behavior, namely; concentration of mind, understanding, respect, fear and admiration for the greatness of Allah, hope for God's forgiveness / mercy, refrain from all heinous actions and shame that arise because of selfawareness of weakness and negligence in carrying out obligations.

Zuhud, what is meant here is that there is a teacher who has an attitude of not being busy with the material of the world, this does not mean that teachers should not have a lot of world material but rather the teacher's ability to manage time to prioritize the interests of religious life. The attitude that arises is to respect each other by giving to each other, not being indifferent to the needs and needs of others, also always remembering Allah SWT.

Tawakal, namely the condition of the teacher where sometimes they are at the point of not finding a solution to the problems of their students or when the conditions of the teacher's daily life are not good, this is where it is necessary to surrender to Allah and always think positively towards Allah's decision. The tawakal attitude also creates a lillahita'ala attitude at work, meaning that it is not in order to exaggerate oneself in front of others. ${ }^{16}$

16 Imam Al-Ghozali, Ihya' Ulumuddin, Jilid 3, Terj. Muh. Zuhri, (Semarang: CV. Asyifa, 1995), 353. 
Istiqomah, which is keeping yourself active in carrying out all the commands of Allah and staying away from everything that $\mathrm{He}$ forbids. In the world of education, this is very necessary considering that a teacher is an example of an attitude that emerges is routine in worship and does not disobey Allah.

Muroqobah, that is, having an ihsan attitude or being kind because you feel that God is always watching over our lives, so that we continue to draw closer to Allah by fully expecting Allah by always carrying out worship with full sense of responsibility. The hope is that the teacher as the holder of the mandate of responsibility for students always pays attention and is responsible for their duties. The muqorobah attitude according to Ibn Qoyyim will lead to my male-behavior as follows; shame of immorality to Allah, calm in character, love for oneself and others, submission, specialization, and fear of Allah.

Preserving the sunnah, which is always taking care to always carry out the Sunnahs of the Prophet in everyday life, this is also a proof of love and taan for Allah and His prophet. Also by eradicating bid'ah, which means a teacher also maintains himself in worship so that he does not fall into acts of worship that are not justified in syar'i and also provides control of the community's worship life by not following deviant things in worship and providing solutions religion whose surroundings are questioned by the community.
Always decorate deeds and work with sunnah, apart from being proof of self-obedience to Allah and the Prophet that carrying out the sunnah can also be a reflection for students in carrying out God's commands. The equality of teachers to students is very much needed in their learning process through the behavior and activities that have been taught by the Prophet Muhammad.

Getting used to life with noble behavior and accustomed to avoiding despicable behavior. One of the reflections for knowledgeable people is that the morals are better and the obedience to Allah will be stronger. So that the better the knowledge of a teacher, the better his morals will be and always stay away from despicable morals.

\section{c. Professional competence}

Professional competence is the ability and skill of both the knowledge and skills of teachers in teaching, guiding, and directing students. Indicators that reflect professional competence according to $\mathrm{KH}$. Hasyim Asy'ari as follows:

The knowledge that the teacher has is really used to achieve the pleasure of Allah, not for the intention of seeking or being a reason for him to get bad things, including getting praise, position, recognition, and honor in front of others. A teacher of Islam must make knowledge as a means of attaining Allah's rido as the highest goal, so that whatever he does with regard to the knowledge he has must be prevented 
from goals that are not justified in shari'ah.

Use knowledge wisely and do not discriminate in using it. The meaning here is how a teacher responds to students in teaching and learning, sometimes a teacher is more concerned with students who are richer or have offspring. More specifically, it is said that a teacher is not allowed to come to students who want to learn but instead students as people who need knowledge from the teacher must go to and meet the teacher.

Always enthusiasm in selfdevelopment in science, worship, writing, reading, repeating lessons, memorizing, discussing, scientific writing, and Islamic syiars. This busyness is part of the teacher's responsibility in developing his knowledge so that it continues to develop according to the times so as not to seem old-fashioned and there is no renewal. There are many things that can be done in achieving scientific improvement for teachers, including by following trainings, reading the latest books, workshops and sharing knowledge.

The teacher always asks about things he doesn't know. The teacher is not ashamed to ask anyone about what he doesn't know, either younger or lower in rank.

Teachers are active as authors of books or scientific articles, writers and summarize the materials needed by their students. Of course, as one of the characteristics of a knowledgeable person who is willing to give his time to write, this is important because one of the ways of syi'ar Islam and science is by writing. ${ }^{17}$ Some even say that people who are knowledgeable but do not have writing then that person is not yet perfect in knowledge related to it cannot be scientifically tested.

The teacher can assess which lessons or material are important and needed at that time for their students. Professional teachers are teachers who are able to deliver lessons with methods according to the conditions and needs. So that the various methods, techniques, and materials presented must be prepared in advance. The delivery of material is expected not to be monotonous so that the objectives that the teacher wants to convey in learning are easily understood by students.

Good at adjusting the intonation of the voice. Interacting in teaching and learning activities must pay attention to voice style and intonation, a good teacher in delivering material is a teacher who can explain slowly and a voice that can be heard by all students. Furthermore, the teacher also takes time for the question and answer session, there may be material that students do not understand. This attitude is an example of the rosul in accordance with the hadith narrated by Abu David. In fact, when the prophet conveyed something, the Prophet used a clear and easily understood voice and articulation.

17 Ramayulis, Samsul Nizar, Filsafat Pendidikan Islam., hlm 233. 
The teacher chooses conducive learning conditions. Among the conducive learning atmosphere is choosing a place and one away from the crowd so that more concentration is done because the atmosphere conducive to learning is part of the learning success factors of students. It is the responsibility of educators to create good learning conditions to get maximum teaching and learning outcomes and with good conditions, learning will make students more comfortable and focus on carrying out learning.

Teachers have good communication skills. The teacher's communication ability is technically needed in learning, with good communication, interaction in learning will run smoothly.

Teachers have high motivation in teaching. This means that a high willingness to carry out the obligations of the teacher in the learning process. This spirit must be cultivated because if a teacher is lazy and lazy in teaching it will have an effect on students and their success in learning.

The teacher also teaches students learning time management. Give attention to the learning activities of students at home by recommending a science course to better understand what has been learned and motivated to memorize lessons as a strong driver of understanding for themselves.

Teachers understand the limits of students' abilities in terms of learning or children's intelligence abilities, by paying attention to students in their learning. If there are students who feel heavy with the material we provide because of its limitations, a teacher must remind and provide material that if they can be accepted by them. Divert learning activities with other positive things to provide refreshments for these students. This may happen when the material presented is difficult or the material should not have been obtained by students, which then the students force themselves to think and understand beyond their current ability.

Teachers have a fair attitude. it means that the teacher does not favoritism in providing knowledge, must not look at the social status of students and is not discriminatory. The goal is that students as a whole can experience learning activities well and can develop their diverse potential.

The teacher is friendly. A friendly attitude towards students in teaching is needed to maintain good relationships with students, facilitate the provision of material, provide comfort to students and be emotionally close to students.

A friendly teacher will give a good impression and is a reflection of the morals of a knowledgeable person. Feelings of reluctance towards the teacher will arise and students will not be afraid to ask about what is the problem in learning. This can be done by getting used to greeting, smiling in a good way of speaking, using good words, and not showing an arrogant attitude to the students.

Trying to create goodness for students and maintain the concentration 
of their minds / Helping students by utilizing what the teacher has, such as social status and assets, if the teacher is able to do that and is not in urgent need. This means that if the teacher has more abilities, a teacher should help alleviate students' problems in terms of material, position (position / job) and so on. Furthermore, in the current digital era in developing student abilities, a teacher must pay attention to the following points;pedagogical competence, competency in the ability to use technology, competence in globalization, competency in future strategic plans, and competency in extension. ${ }^{18}$

If there are class students or study participants absent as usual, then the teacher must ask him, what are the conditions, and who are the relationships. The teacher should ask other students if one of the students is not present in teaching and learning activities. From the attention of teachers to students, harmony will be created between teachers and students. Because basically students will feel happy with the character of the educators giving the attention mentioned above.

A teacher should humble a student or anyone who asks about his personality with Allah Ta'ala. This means that in every teacher's behavior, the teacher does not highlight the arrogant attitude of his profession,

18 M. Anwar Nurkholis dan Badawi, (2019) Profesionalisme Guru Di Era Revolusi Industri 4.0, Prosiding Seminar Nasional Pendidikan Program Pasca Sarjana Universitas PGRI Palembang, 12 Januari. 479. always gives the best responses to his questions with the aim of broadcasting the knowledge he has and always tries to explain the oneness of Allah by providing statements that understand and can get closer to Allah. . Talk to every student, especially students who have strengths, with words that show respect and appreciation.

Teachers are obliged to treat students well. Such as calling him with good names and titles, welcoming them, answering their greetings and asking how they are and how they are. Familiarity with students must be present at every moment this also arouses and motivates students' learning in gaining knowledge. That way the teacher will find it easier and more flexible to testify about virtue

\section{d. Social competence}

Social competence is the ability of individuals to collaborate with other individuals, in which it involves good interactions, has good feelings for others, and is skilled at making knowledge to establish good communication. Indicators that reflect professional competence according to $\mathrm{KH}$. Hasyim Asy'ari as follows:

As a teacher, you should also be able to choose various daily activities, including choosing a livelihood. Do not let teachers become part of groups with professions that are sanctioned and even prohibited by Allah SWT. The profession that should be chosen is a profession that is blessed in accordance with religious guidance and can maintain the spirit of teachers in their social life. 
A teacher should pay attention to the place and social conditions where he congregates and interacts. Often being or gathering in a place that is not socially good will greatly impact the public's view of the teacher. As an example of a teacher who has a hobby in the world of motor racing, then he is often involved in activities and the community of wild racing will certainly bring down the teacher's muru'ah, and in the eyes of the community the teacher is considered unable to practice and provide good examples for the community. By always maintaining a place where teachers gather and interact shows respect for their knowledge and profession as a teacher.

Accustomed to interacting with others with good morals / behavior. The social life of teachers is always a concern for the community because of the current strategic position of teachers who are considered to be knowledgeable and have something more than society in general, so that it is to establish this relationship that a teacher is expected to always behave well. Good character can be reflected through everyday attitudes such as smiling when meeting other people, speaking softly, understanding the position or position of each person so that they do not think that their rank is always higher in front of the community, and always protecting the environment without causing disturbances or problems. and prioritize common interests rather than personal.

Teachers become role models by paying attention to things that will take care of interactions among fellow students. Familiarize yourself and provide examples to students about how to get along well. As a teacher is the inheritor of the prophets, the teacher must imitate how the prophet provides an example to his people in his words and actions, not only in the school environment but more than that in the community environment as well as teachers ready to be good role models.

\section{Conclusion}

Three teacher positions according to KH. Hasyim Asy'ari, namely the teacher as an individual is the competence or ability of the teacher regarding religious personal, meaning that a teacher must have an attitude or ability regarding the teacher's personal self, including the teacher's religious attitude, exemplary, wise and has an attitude of affection. when teaching teachers, the activities of a teacher begin with planning teaching and learning, implementing, until the learning process ends. $\mathrm{KH}$ Hasyim Asy'ari gave his opinion that for a teacher to always be available in learning by making the best preparation in teaching. teachers to students, teaching and learning activities including the interaction of teachers and students.

Pedagogic competence is the ability to manage student learning. The pedagogic competence indicator according to KH. Hasyim Asy'ari includes the attitude of purifying 
himself from everything that is not blessed by Allah Almighty, visionary teachers or those with goals, teachers approach and have knowledge in accordance with their fields.

Personality Competencies, namely the individual abilities of teachers related to teacher behavior and personalities as role models for students. personality competence covers several aspects, namely; a person who is calm, tawakal, tawadhu ', and mantab, an independent person, is wise, dignified, has noble character, and always reflects an attitude of maturity in accordance with the prevailing norms.

Professional competence is the ability and skill of both the knowledge and skills of teachers in teaching, guiding, and directing students. Indicators that reflect professional competence according to KH. Hasyim Asy'ari is a teacher's ability in knowledge, is wise in using knowledge, does not discriminate in using knowledge, is active in developing both knowledge and skills, is good at managing voice intonation, is good at choosing subject matter, is able to create good conditions in learning, and is able to develop the potential of participants. students.

Social competence is the ability of individuals to collaborate with other individuals, in which it involves good interactions, has good feelings for others, and is skilled at making knowledge to establish good communication. Indicators that reflect professional competence according to
KH. Hasyim Asy'ari is good at choosing jobs, good at choosing communities where to gather, avoiding places that socially can reduce the degree of teachers, and is able to interact well with the community and its existence is a solution to problems that exist in his community.

\section{REFERENCES}

Abdul Majid, Belajar dan Pembelajaran Pendidikan Agama Islam, Bandung, PT. Remaja Rosdakarya, 2012.

Abuddin Nata, Figures of Renewal of Islamic Education in Indonesia, Jakarta; Raja Grafindo Persada, 2005,

Effendi, Ridwan. Etika Profesi Guru. Bandung: Penerbit Alfabeta, 2014.

Evita, E., Syahid, A., \& Nurdin, N. (2019). Understanding Students' Learning Outcomes Differences Through the Application of the Market Place Activity Type of Cooperative Learning Model and the Application of Conventional Learning Models International Journal of Contemporary Islamic Education, 1(1), 67-85.

Gunawan, Heri. Pendidikan Islam Kajian Teoritis dan Pemikiran Tokoh. Bandung: PT Remaja Rosdakarya, 2014.

Hadi, Sutrisno. Metodologi Research. Yogyakarta: Andi Offset. 1990.

Hasyim As'ari Tebuireng Thought Research Center Team, 2018, Actualization of Thought and 
Justice, Jombang, Pustaka

Tebuireng.

Ilyas, Yanuar. Kuliah Akhlak.

Yogyakarta: Pustaka Pelajar Offset. 1999.

Imam Al-Ghozali, Ihya' Ulumuddin, Jilid

3, Terj. Muh. Zuhri, Semarang, CV. Asyifa. 1995.

Kurniati, K., Nurdin, N., \& Nurasmawati, N. (2020). Improving Students' Cognitive and Affective Domains Students through Fostering Teacher Development International Journal of Contemporary Islamic Education, 2(2), 56-70.

KHM Hasyim Asy'ari, Achieving Success in Teaching and Learning, trans. M. Tholut Mughni Jombang: Multazam Press. 2011.

KHM Hasyim Asy'ari, Islamic Education; KHM Hasyim Asy'ari's Advice for Teachers (Kyai) and Students (Santri), trans. Mohamad Kholil, Yogyakarta: Titian Wacana. 2007.

M. Anwar Nurkholis dan Badawi, Profesionalisme Guru Di Era Revolusi Industri 4.0, Prosiding Seminar Nasional Pendidikan Program Pasca Sarjana Universitas Pgri Palembang 12 Januari 2019.

Moh Uzer Usman, menjadi guru proffessional bandung remaja rosdakarya. 2009.

Moh. Metode penelitian. Jakarta:Ghalia Indonesia. 1988.

Mojlun Khan, Muhammad. 100 Muslim Paling Berpengaruh Sepanjang Sejarah. Jakarta: Noura Books Mizan Publika, 2012.
Muhaimin, Development of Islamic Education Curriculum for Schools, Madrasas and Universities, Jakarta: Raja Grafil Persada, 2005.

Muhammad Hasyim Asy'ari, Adab al'Alim wa al-Muta'allim Jombang: Turats al-Islamy, $1515 \mathrm{H}$.

Murtiningsih, Wahyu. Biografi Para Ilmuwan Muslim. Yogyakarta: Pustaka Insani Madani, 2008.

Nanang Hanafiah, Cucu Suhana, The Concept of Learning Strategies, Bandung: PT. Repika Aditama, 2010.

Nata, Abuddin. Akhlak Tasawuf. Jakarta: PT RajaGrafindo Persada, 2002.

Nawawi, Hadari, Pendidikan Dalam Islam. Surabaya: Al Ikhlas Nazir, 1993.

Nur Uhbiyati, Islamic Education. Cet II: Bandung: Faithful Center. 1997.

Rahmaniyah, Istighfarotur. Pendidikan Etika Konsep Jiwa dan Etika Perspektif Ibnu Miskawaih Dalam Kontribusinya di Bidang Pendidikan. Malang: UIN-Maliki Press, 2010.

Saifuddin Azwar, Research Methods, Yogyakarta: Student Library, 2009.

Sanapiah Faisal, Educational Research Methodology, Surabaya: National Business. 1982.

Sukardi, Metodologi Penelitian

Pendidikan; kompetisi dan prakteknya, PT. Bumi Aksara, Jakarta, 2007.

Winarno Surakhmad. Pengantar Penelitian Ilmiah Dasar Metode Teknik. Bandung: Tarsito. 2001. 
Zulfatmi, 2017. Spiritual Competence of Educators (A Study on the Elements of the Heart). Mudarrisuna Journal: Media for Islamic Religious Education Studies. 7. 149.10.22373 / jm.v7i2.2360.

Zumrotul Mukaffa, DEPRIVASI RELATIF KOMPETENSI KEPEMIMPINAN GURU PAI: Kajian Komparatif Guru Akidah Akhlak Berkualifikasi S1 dan Guru Tugas Pesantren Lulusan MA, Jurnal Epistemé, Vol. 13, No. 1, Juni 2018 